\title{
On expletive subject pronoun drop in Colloquial French $^{\mathrm{I}}$
}

\author{
MICHAEL ZIMMERMANN AND GEORG A. KAISER
}

(Received January 2013; revised August 2013; first published online I7 December 2013)

\begin{abstract}
This paper sets out to contribute to the debate on the morpho-syntactic status of phonologically weak or clitic subject pronouns in Colloquial French by discussing finite impersonal constructions in which the expletive subject pronoun is nonexpressed. The paper provides arguments against an approach in terms of inflectional affixes, showing that the non-expression of this pronoun is in fact syntactically restricted. On the basis of the further finding that the non-expression of the expletive represents the continuation of a grammatical trait of older stages of the language in which the non-expression of subject pronouns was generally possible, a tentative proposal is put forward which crucially draws on information structure.
\end{abstract}

\section{INTRODUCTION}

Ever since the beginning of Romance linguistics, the morpho-syntactic status of phonologically weak or clitic subject pronouns in Modern French has been heavily debated. ${ }^{2}$ In the context of this debate, two opposing approaches to the status of these elements have been put forward, namely an approach in terms of phonological clitics and one in terms of inflectional prefixes. Under the former approach, the elements under discussion are morpho-syntactically independent words, i.e. argumental subjects in their own right, which cliticise to the finite verb in the phonological component. According to the latter approach, these elements represent agreement marking affixes which combine with the finite verb in the morphological component.

1 This study was carried out as part of the binational research project 'Dialectal, acquisitional, and diachronic data and investigations on subject pronouns in GalloRomance' (DADDIPRO), funded by the Deutsche Forschungsgemeinschaft and the Agence Nationale de Recherche (German and French, respectively, Research Foundation). Thanks to Melissa Ingersoll, Maialen Iraola, Bart Jacobs, Stefano Quaglia, Sandra Tinner, and three anonymous reviewers for helpful comments on a draft version of this paper.

2 Cf. Meisenburg (2000) and Kaiser (2008) for a general overview. 
While clitic subject pronouns in Standard French (SF) have been shown to constitute phonological clitics, the issue of whether or not these pronouns likewise represent phonological clitics in Colloquial French (CF) has not yet been settled. ${ }^{3}$ This paper sets out to contribute to this ongoing debate by discussing an intriguing characteristic of CF which has seldom been addressed and which may prove to be of great(er) relevance for the eventual analysis of clitic subject pronouns: finite constructions without any subject. CF in fact features two such types of constructions, namely personal constructions such as in (Ia) and impersonal constructions (ICs) such as in ( $\mathrm{Ib}$ ) in which clitic referential and expletive, respectively, subject pronouns are non-expressed.

(I) a. connais

pas (Gadet, I997: 70)

know.Ist.Sg not

'I don't know'

b. faut voir (Gaatone, I976: 245, fn.I)

must.3rd.Sg to.see

'we'll see'

Contrary to the latter type of constructions, the former type constitutes a highly restricted conventionalised set, in that the non-expression of clitic referential subject pronouns is possible only with verbs such as connaitre 'to know', croire 'to think', and savoir 'to know' when negated and in the Ist person singular (Gadet, I997: 70). ${ }^{4}$ In the following, constructions such as in $(\mathrm{Ib})$ will be looked into and their implications assessed with respect to the morpho-syntactic status of clitic subject pronouns in CF. We will show that the non-expression of expletive subject pronouns may not be readily considered evidence for the approach to the status of clitic subject pronouns in CF in terms of inflectional affixes. On the basis of the crucial findings that (i) the non-expression of the former pronouns represents the continuation of a grammatical trait of older stages of French and that (ii) it seems to be syntactically restricted, it will be tentatively argued that the non-expression of expletive subject pronouns in CF follows from the same reasons as the non-expression of subject pronouns in Medieval French, namely from the movement of the finite verb to the left periphery.

\section{ICS WITH NON-EXPRESSED EXPLETIVE SUBJECT PRONOUNS}

I N C F

In comparison to SF in which the expression of the clitic expletive subject pronoun il 'it' $(I L)$ in (finite) ICs is generally obligatory, the principal exception being fixed

3 The term 'CF' is commonly used in the literature to refer to a variety of French which shows significant differences from SF, 'disregard[ing] the norms taken as characterising "good usage" (Zribi-Hertz, I994: 460).

${ }^{4}$ Cf. also Meisenburg (2000: 232) as well as Grevisse and Goosse (20 I I 234) who additionally give some scattered examples of the non-expression of $3^{\text {rd }}$ person referential subject pronouns. 
expressions showing characteristics of older stages of French (e.g. mieux vaut faire ... 'it is better to do ...'), CF stands out due to the frequent non-expression of $I L$. This non-expression of $I L$ is, however, not categorical, nor does it extend to constructions with all impersonal verbs. Resulting from a close examination of relevant indications in the literature (cf. (3) for pertinent references), constructions with the following set of impersonal verbs only may have IL non-expressed in $\mathrm{CF}$ :

(2) s'agir 'to concern', $y$ avoir 'to exist', être 'to be' + noun, faire 'to make' + adjective (+ infinitive), faire 'to make' $+d e$ 'of' + article + noun, falloir 'to have to', s'en falloir 'to be close to', paraître 'to appear', sembler 'to seem', suffire 'to be sufficient', valoir mieux 'to be better'

The examples in (3) illustrate the non-expression of $I L$ in ICs with these verbs.

(3) a. S' agit maintenant de sortir d' ici.

itself is.matter.of now of to.leave from here

(Chigarevskaia, I968: 363)

'We must now leave this place.'

b. Y a de l' eau. (Maillard, I985: 74f.)

there has of the water

'There is water.'

c. S'rait p't êt' temps d' affûter ses pincettes. would.be may to.be time to to.sharpen one's tweezers (Sandfeld, I965: 20)

'It is maybe time to show one's claws.'

d. Fait pas chaud ce matin. (Leeman, 2006: 25)

makes not hot this morning

'It is not hot this morning.'

e. Fait du vent. (Maillard and Almeida, 2000: I9I)

makes of.the wind

'It is blowing.'

f. Faut pas s' en faire. (Oppermann-Marsaux, 2006: I3)

must not oneself of.it to.make

'One should not worry.'

g. S' en est fallu de peu. (Heriau, I980: 99)

itself of.it is had.to of little

'That was a near miss.'

h. Paraît qu' on s' est trompé. (Buridant, 2007: 428)

appears that we ourselves is deceived

'It appears that we made a mistake.' 
i. Me semble que c' est bonne idée. (Dupuis, I988: 47) to.me seems that this is good idea 'It seems to me that this is a good idea.'

j. Suffisait d'y penser. (Le Goffic, I993: I 59) is.sufficient to there to.think 'It is obvious when you think about it.'

k. Vaudrait mieux pas. (Berrendonner, I993: 26) would.be.worth better not 'You had better not!'

As far as the respective frequencies of the non-expression of $I L$ in constructions with the impersonal verbs in (2) are concerned, it is generally stated that these show significant differences. Specifically, ICs with $y$ avoir 'to exist' and falloir 'to have to' are argued to be most frequently encountered with non-expressed $I L$, ICs with faire 'to do' + adjective (+ infinitive) and valoir mieux 'to be better' are claimed to come second in frequency, while in ICs with paraitre 'to appear', sembler 'to seem', and suffire 'to be sufficient', the non-expression of $I L$ is said to be infrequent. ${ }^{5}$

\section{MORPHOLOGICAL CONCEPTIONS OF THE NON-EXPRESSION OF}

\section{IL IN ICS}

In the debate on the morpho-syntactic status of clitic subject pronouns in CF, the intriguing characteristic of CF to have IL non-expressed in ICs has been considered (further) evidence for approaching these pronouns in terms of inflectional affixes. We shall discuss these conceptions and will show that they fall short of adequately capturing the non-expression of IL. From this we shall conclude that the nonexpression of IL may not be readily considered (further) evidence for the approach in terms of inflectional affixes.

\subsection{ICs with non-expressed IL as arbitrary lexical gaps (Auger, 1993)}

Auger (I993) applies the set of criteria established in Zwicky and Pullum (I983) to differentiate between phonological clitics and inflectional affixes to clitic subject pronouns in CF. In the context of this application, she claims that the non-expression of $I L$ in CF represents a 'morphological argument' for an approach in terms of inflectional prefixes. Specifically, Auger (I993: I79) considers the observation that constructions with non-expressed clitic subject pronouns are encountered only with 'a few impersonal verbs in Colloquial French' an instantiation of Zwicky and Pullum's (1983) criterion B and argues that such

5 We have not come across any relevant indications regarding the frequency of the nonexpression of $I L$ in constructions with the rest of the impersonal verbs given in (2). 
constructions constitute arbitrary lexical gaps. These are claimed by Zwicky and Pullum (I983: 504) to be 'more characteristic of affixed words than of clitic groups'.

Yet, there are good reasons to believe that ICs with non-expressed IL in CF do not constitute arbitrary lexical gaps. In their initial abstract definition, Zwicky and Pullum (1983: 505) consider arbitrary lexical gaps 'cases where $[\ldots]$ some single expected host-clitic combination fails to occur'. Later on, in the context of their discussion of the morpho-syntactic status of the English negative formative n't, Zwicky and Pullum (1983: 507) expound on what exactly they consider to be arbitrary lexical gaps: combined forms which 'do not exist at all' such as *mayn't and *amn't. According to Zwicky and Pullum (1983), then, arbitrary lexical gaps are instances in which one element categorically fails to combine with another one, and this on no principled grounds. Against this background, the non-expression of $I L$ in ICs in CF may hardly be considered an instance of Zwicky and Pullum's (I983) criterion B. For as follows both from section 2 and from the relevant indications given by Auger (I993) herself, in CF, the non-expression of clitic subject pronouns in finite constructions without any other subject is neither categorical, nor is it arbitrary.

It is widely acknowledged that in CF, clitic subject pronouns are never categorically non-expressed in finite constructions, but only optionally so (Koch and Oesterreicher, 20Iг: II7). We shall provide independent empirical evidence, since the optionality of the non-expression of clitic subject pronouns is generally deduced from introspection only. Given that in the context of the approach to clitic subject pronouns in CF in terms of inflectional prefixes, the notion of (more or less constant) code-switching between CF and SF is generally adduced (Culbertson, 20Iо; Zribi-Hertz, 201 I), the methodology of introspection is quite problematic in this context. In order to be able to give such empirical evidence, an independent morpho-syntactic device is needed which allows for the unequivocal classification of a given IC as either CF or SF. In fact, such a device is readily at hand, namely the (non-)expression of the preverbal negative particle $n e$ in the context of sentential negation: while in SF, this particle is categorically expressed, usually together with the postverbal adverbial negative marker pas, it is generally non-expressed in CF, pas then being the sole marker of sentential negation (Söll, I985: II9; Rowlett, I998).

With this background in mind, we have searched three modern synchronic data corpora of spoken French ${ }^{6}$ for instances of negated finite constructions with the impersonal verb falloir 'to have to' and pas as the sole marker of sentential negation. The search results, given in Table I and illustrated in (4), show that all of the three data corpora feature instances of both the expression and the non-expression of $I L$ in the constructions under investigation.

6 The modern synchronic data corpora of spoken French processed are the following: a computerized part of the GARS (Groupe Aixois de Recherches en Syntaxe) corpus featuring around 444,000 words, Eschmann (1984), and sections I-VII of Ludwig (1988). 
Table I. Sequences of '(IL + ) finite form of falloir 'to have to' + pas 'not'

\begin{tabular}{lcccr}
\hline \hline corpus & & $I L$ expressed & $I L$ non-expressed & $\Sigma$ \\
\hline GARS & $\#$ & 80 & 3 I & I I I \\
& $\%$ & $72 . \mathrm{I}$ & 27.9 & I \\
Ludwig (I988) & $\#$ & 5 & 4 & 9 \\
& $\%$ & 55.6 & 44.4 & I \\
Eschmann (1984) & $\#$ & 2 & 3 & 5 \\
& $\%$ & 40 & 60 & I \\
\hline \hline
\end{tabular}

(4) a. non franchement il faut pas y aller (GARS, PCR-RooPRIooi) no really it must not there to.go 'no, really, you don't have to go there'

b. faut vraiment pas y aller (GARS, PCR-RooPRIooi) must really not there to.go 'you don't really have to go there'

We take this finding as an unequivocal indication that in CF, clitic (expletive) subject pronouns are never categorically non-expressed in finite constructions.

Note, furthermore, that with the exception of constructions such as in (Ia) which are generally taken to constitute a highly restricted conventionalised set, the non-expression of clitic subject pronouns in finite constructions without any other subject is solely encountered with (certain) impersonal verbs. We take this as a clear indication that in CF, the non-expression of these pronouns is not arbitrary, but follows from principled grounds. In light of these considerations, then, the nonexpression of IL in ICs in CF may be shown not to represent arbitrary lexical gaps.

\subsection{ICs with non-expressed IL as precursors to a new change (Fonseca-Greber, 2004)}

Fonseca-Greber (2004: 86) considers the non-expression of IL in ICs in CF both a clear indication of the (near) completion of the morphologisation of clitic subject pronouns and the 'leading edge of a new change' (cf. also Haas, I909: 53; Seefranz-Montag, I983; I984; Culbertson, 2010). Specifically, she conceives of this non-expression of $I L$ as 'the internal restructuring of the new prefixal verb paradigm through the emergence of a zero morph, restricted for the present to [a] communicatively clear subset of the $3 \mathrm{Sg}$.: impersonal verbs' (Fonseca-Greber, 2004: 86). Both conceptually and empirically, however, this claim does not stand up to closer examination.

From a conceptual point of view, it is entirely unclear why, as noted by FonsecaGreber (2004: 8I) herself, '[a]t a time when clitic use is on the rise in most linguistic contexts [...] certain impersonal verbs appear sans clitic, apparently in flagrant violation of the general trend toward morphologised verbal prefixes'. Rather than being a consequence of the alleged morphologisation of clitic subject pronouns in CF, the non-expression of IL in ICs represents a clear contradiction, and this all the more so, since, as pointed out by Fonseca-Greber (2004: 84), 'morphologization 
is approaching completion in the $3^{\text {rd }}$ person', while in the $\mathrm{I}^{\text {st }}$ and $2^{\text {nd }}$ person, it is arguably complete. In fact, under the assumption that the non-expression of clitic subject pronouns is a consequence of the near completion of their morphologisation, one would naturally expect those pronouns to be the precursors to a subsequent change which have already been completely morphologised, namely those of the ${ }_{1}{ }^{\text {st }}$ and / or $2^{\text {nd }}$ person; yet, this is not the case. FonsecaGreber (2004: 84) tries to circumvent this conceptual objection by noting that ' $[\mathrm{m}]$ orphologization is complete with $3 \mathrm{Sg}$. verbs that disallow a referential subject, as in weather verbs [...] and impersonal verbs'. Even if one were to grant this circumvention, the proposed analysis is still conceptually problematic. For why should of all verbs (certain) impersonals be the precursors to a subsequent change? Since, Fonseca-Greber (2004: 83) argues, 'impersonal verbs [...] (a) exist only in the $3^{\text {rd }}$ person and (b) cannot take a referential subject'. ${ }^{7}$ Rather than corroborating her analysis, however, this functional explanation severely undermines it.

First of all, if expletive subject pronouns were functionally that useless, it is unclear why they were integrated into the language earlier on. Second, under the view that clitic subject pronouns in CF are agreement marking prefixes, one would naturally expect these elements to be categorically expressed, since they evidently fulfill a specific functional role. Third, the non-expression of $I L$ is not restricted to ICs with genuine impersonal verbs such as falloir 'to have to', but is also encountered in ICs with verbs such as suffire 'to be sufficient' whose conjugation is not restricted to the $3^{\text {rd }}$ person singular and which also combine with subject elements other than IL. Fourth, among the constructions with genuine impersonal verbs, IL may be non-expressed with a small subset of these verbs only. Fifth, if $I L$ was functionally useless in constructions with certain impersonal verbs, it is entirely unclear why in these very constructions, its non-expression is not categorical or, put differently, why $I L$ is (still) expressed, indeed frequently, as follows e.g. from the data given by Fonseca-Greber (2004) herself. ${ }^{8}$

In addition to these conceptual drawbacks, the claim that ICs with non-expressed $I L$ constitute the precursor of a new change in CF also faces a severe empirical drawback, since such ICs are not recent phenomena. In fact, the non-expression of $I L$ in ICs in CF is generally taken to represent the continuation of a grammatical

7 Cf. also Chigarevskaia (I968), Heriau (I980), and Maillard (1985) who consider the nonexpression of $I L$ in CF to directly result from, on the one hand, the instant recognisability of the relevant constructions as ICs and, on the other, from 'rhetorical economy' (Heriau, I980: 104).

8 With regard to her corpus data, Fonseca-Greber (2004: 89) claims that IL is categorically non-expressed in finite constructions with $y$ avoir 'to exist'. Note, however, that among ICs, these constructions exclusively allow for the phonological phenomenon of haplology. Specifically, in finite constructions with $y$ avoir 'to exist', $I L$ is generally argued to phonologically reduce to [i]; this leads to a sequence of two identical vowels resulting in vowel syncopation (Damourette and Pichon, I934; Picoche and Marchello-Nizia, I998; Grevisse and Goosse, 20II). It is thus in principle not possible to tell whether in finite constructions with $y$ avoir 'to exist' in CF, IL is actually (non-)expressed. 
trait of older stages of French in which all ICs may have IL non-expressed (Brunot, I89I; Haas, I909; Brugmann, I9I7), as illustrated in (5a) for weather verbs, in (5b) for verbs whose conjugation is restricted to the 3 rd person singular and which solely combine with $I L$, and in (5c) for verbs whose conjugation shows no such restrictions (Zimmermann 2012).

(5) a. Lors si conmença a ajorner,... (conqueste, [I290], p. I32)

then so started to to.become.light

'Then it thus started to become light, ...'

b. Quant Franceis veient que paiens i ad tant,...

when French see that pagans there has so.many

(roland, [I I25-I I 50], p. 27I)

'When the French see that there are so many pagans, ...'
c. ..., que onques n' en demoura avec le roy fors que
that never not of.them stayed with the king except that
.II. ou .III.. (louis, [I330-I340], p. I 86)
two or three
'..., that never more than two or three of them stayed with the king.'

Note, however, that virtually no empirical evidence has been provided so far to corroborate this general claim, at least as far as the period from the mid-I 7 th to the mid-Igth century is concerned. In fact, Steinmeyer (I979: 2I9f.), referring back to relevant observations by grammarians, is the only researcher who provides a few scattered examples of ICs with non-expressed IL for the second half of the I7th century as well as for the middle and end of the I 8th century.

To compensate for this general lack of empirical evidence for the common claim of the continuation of the non-expression of $I L$ in ICs in CF, we have, in light of the general absence of diachronic corpora of CF, sifted through numerous pieces of literary work from the mid-I th to the end of the I9th century in search of instances of constructions with the $3 \mathrm{rd}$ person singular present indicative impersonal verb form faut 'must' and non-expressed IL. The pieces of literary work we looked at principally constitute comedies which are generally considered most likely to contain instances of CF (Steinmeyer, I979: 219; Gadet, I997: I I). For this literary genre stands out due to both its more or less consistent conversational / dialogical nature and its frequent recourse to characters representing members of the lower classes which are commonly associated by contemporary authors with a general lack of education and, more importantly in this regard, the occasional ignorance of SF. This ignorance is evidently a direct reflection of the lack of education and, to all appearances, a prominent means of illustrating this deficiency (Siede, I885: I). Independent evidence for the soundness of such a conjecture comes from relevant rebukes by contemporary grammarians such as Chiflet (I659). Because of its relevance, his rebuke proves to be all the more pertinent in the present discussion, as it unequivocally indicates that the non-expression of $I L$ is indeed a trait of the spoken language and continues right into spoken Modern French: 'Never say Faut 
faire cela ['One must do this'], Faut prendre garde ['One must watch out'] without adjoining $\mathrm{Il}$, as do the people from the Provence'. ' (Chiflet, I659: 85).

Contrary to what one may expect, however, our examination of various pieces of literary work from the period under investigation exposes that the non-expression of $I L$ with faut 'must' is comparatively seldom encountered. In fact, relevant instances are few and far between, a state of affairs which most probably results from the general expectation that authors adhere to (the speech ideal of) SF (Diehl, I895: I; Rohlfs, I928: 4). In any case, what is crucial in this regard is that instances of ICs with non-expressed IL are encountered from the mid- $I 7^{\text {th }}$ to the end of the $19^{\text {th }}$ century, and this consistently so. Lack of space prevents us from listing all I I 3 pieces of literary work established in which at least one instance of constructions with faut 'must' and non-expressed IL is encountered as well as giving all of the 306 relevant instances. By way of illustration, we shall therefore only provide one example of the non-expression of IL in constructions with faut 'must' for every quarter of a century of the period under investigation.

(6) a. ..., faut assassiner nuitamment Le traitre qui... must to.kill in.the.night the traitor who (boutades, I647, pp. Io6f.)

'..., the traitor who ... must be killed in the night.'

b. Faut ... (sganarelle, I660, p. 23)

must

'One must ...'

c. Faut qu' il ait bonne bourfe fthomme-là. (lotterie, I697, p. 25) must that he have good purse this.man there

'This man there must really have a big purse.'

d. ..., nous vela riche, faut prendre garde à ça. (heritier, I 729, p. 9) we there rich must to.take care to this

'..., we are rich now, we must take notice of this.'

e. ... : faut servir sa maitresse. (nanine, I750, p. 267)

must to.serve his mistress

'.... one must serve his mistress.'

f. ; \& faut bien que ça foit vrai, ... (barbier, I775, p. 39) and must well that this be true

'; and this had better be true, ...'

g. Allons, voisin, faut commencer la journée gaiement,... come.on neighbor must to.begin the day cheerfully (sabotiers, I796, p. I I)

'Come on, neighbor, one must begin the day cheerfully, ...'

9 Our translation. The original reads: 'Ne dites jamais ; Faut faire cela ; Faut prendre garde ; fans y ajouter $I l$ : comme parlent les Provençaux'. 
h. ..., faut lui faire plaisir à ce brave homme. must him to.make pleasure to this decent man (accordée, I 824 , p. I I)

'..., one must please this decent man.'

i. Faut vous en aller tout de suite... (ange, I 848, p. 4) must yourself of.it to.go all of rest 'You must immediately leave ...'

j. Faut me taire...(brigands, I87I, p. 7) must myself to.keep.quiet 'I must keep quiet ...'

k. V'là d' la brume, m'sieur Pierre, faut rentrer. (pierre, I888, p. IOo) there of the mist mister Pierre must to.return 'It gets misty, Mr Pierre, we must return.'

In light of this unequivocal empirical evidence showing that ICs with nonexpressed $I L$ represent the continuation of a grammatical trait of older stages of French as well as in light of the conceptual drawbacks elaborated on above, the non-expression of IL in ICs in CF may be compellingly shown not to constitute the precursor of a new change.

\section{$3 \cdot 3$ Intermediate summary}

The preceding discussion of the different conceptions of the non-expression of $I L$ in ICs has shown that the linguistic reality of this intriguing characteristic of CF is even more intricate than previously assumed. Specifically, this non-expression of $I L$ is neither categorical, nor arbitrary. What is more, it represents the continuation of a grammatical trait of older stages of French in which the non-expression of subject pronouns was generally possible. From these findings we shall therefore conclude that the non-expression of IL may not be readily considered (further) evidence for approaching the status of clitic subject pronouns in CF in terms of inflectional affixes.

\section{SYNTACTIC RESTRICTIONS ON THE NON-EXPRESSION OF $I L$ IN ICs}

In this section, we shall present new insights into the non-expression of $I L$ which seem to suggest that it in fact represents evidence against the approach to clitic subject pronouns in CF in terms of inflectional prefixes.

In the literature, it has been argued that a strict correlation holds between the (non-)expression of $I L$ and the (non-)embeddedness of ICs. Specifically, it has been claimed that whenever these constructions are embedded, IL is consistently expressed, as illustrated in (7). ${ }^{10}$

10 Cf. also Maillard (I985) according to whom the expression of IL in embedded clauses may additionally follow from phonetic reasons, namely the so-called loi de trois consonnes. 
(7) a. *Je lui ai dit que faut pas travailler trop

I him have said that must not to.work too.much

(Gabriel and Müller, 2013: I 5)

'I told him that one does not have to work too much'

b. *Il dit que faut faire ce travail (Kaiser, 2008: 3 I5)

he says that must to.make this work

'He says that this work needs to be done'

If this were indeed the case, it would imply that the non-expression of IL relates, at least to some extent, to syntax, a state of affairs which would represent direct counterevidence to the approach to clitic subject pronouns in CF in terms of inflectional prefixes.

So far, no (extensive) empirical evidence has been provided which independently corroborates the claim presently discussed. Yet, on the basis of a search of a part of a modern synchronic data corpus of spoken French (CREDIF (Centre de Recherche et d'Etude pour la Diffusion du Français)), Barme (2012) refutes the claim under discussion. He does so by providing what he considers instances of embedded finite constructions with $y$ avoir 'to exist' and falloir 'to have to' in which IL is non-expressed.

Note, however, with regard to the relevant instances with $y$ avoir 'to exist' that in $\mathrm{CF}$, finite constructions with this verb stand out due to a concurrence of two phonological specificities, namely the pronunciation of $I L$ as [i] and haplology (cf. footnote 8). In this regard, then, it is in principle not possible to tell whether $I L$ is actually (non-)expressed in finite constructions with $y$ avoir. In light of this state of affairs, one had therefore better not draw on instances of embedded finite constructions with $y$ avoir 'to exist' to refute the claim presently discussed. As for the relevant instances with falloir 'to have to', out of Barme's three counterexamples, given in (8), two represent root, rather than embedded constructions (cf. (8ab)). The total amount of unequivocal counterevidence provided by Barme (20I2: $7 \mathrm{I}$ ) is thus eventually reduced to one single embedded finite construction with non-expressed $I L$, namely the one given in (8c).

(8) a. puis le bonhomme il lui a dit faut lui amener sa then the guy he him has said must him to.bring his

voiture à Starky/ (CREDIF, FEI, I 58, quoted from Barme, 20I2: 7I) car to Starky

'then the guy told him: "You must bring Starky his car"

b. On peut faire euh: un BTS mais faut faut bien travailler/ we can to.make er a BTS but must must well to.work

faut aller en première de réadaptation.

must to.go in first of readjustment'

(CREDIF, HJ4, I64, quoted from Barme, 20I2: 7I)

'We can do er a BTS; but we must work well, we must attend a readjustment course.' 
c. ... ils ont tout sous la main/ tandis que chez nous faut they have all under the hand while at ours must aller a- assez loin/ (CREDIF, HJ4, 387, quoted from Barme, 20 I2: 7I) to.go qu- quite far

'... they have all to hand, while at our place, one must go quite far'

In the literature on ICs, we have come across one further (isolated) embedded finite construction with non-expressed $I L$, namely the one in (9a); moreover, we have encountered another relevant construction in a movie title, given in (9b).

(9) a. Je me dit [sic!] que fallait pas continuer.

I myself say that was.having.to not to.continue

(Berrendonner, I993: 26)

'I told myself that I had better not continue.'

b. Quand faut y aller faut y aller. (movie title)

when must there to.go must there to.go

'A man's gotta do what a man's gotta do!'

In light of the overall small number of counterexamples, we have searched the selected three modern synchronic data corpora of spoken French for instances of embedded finite constructions with falloir 'to have to'. As can be seen in the results of this search, given in Table 2, two out of the three selected data corpora feature (a comparatively small number of) instances of such constructions with non-expressed IL (cf. (Io) for relevant illustrations).

Table 2. Embedded finite constructions with falloir 'to have to'

\begin{tabular}{|c|c|c|c|c|}
\hline corpus & & IL expressed & IL non-expressed & $\overline{\Sigma \Sigma}$ \\
\hline \multirow[t]{2}{*}{$\overline{\text { GARS }}$} & $\#$ & 287 & 24 & 3 I I \\
\hline & $\%$ & 92.3 & $7 \cdot 7$ & IOO \\
\hline \multirow[t]{2}{*}{ Ludwig (I988) } & $\#$ & I9 & o & I9 \\
\hline & $\%$ & 100 & $\mathrm{O}$ & IOO \\
\hline \multirow[t]{2}{*}{ Eschmann (I984) } & $\#$ & 7 & I & 8 \\
\hline & $\%$ & 87.5 & I 2.5 & $\mathrm{IOO}$ \\
\hline
\end{tabular}

(Iо) a. que pour garder pour le travail faut s' arranger that for to.keep for the job must oneself to.get.along (GARS, BAY-RooPRIoor)

'that in order to keep the job, one must get along'

b. ma mère savait à peu près tel jour combien

my mother was.knowing to little near that day how.much

fallait de pain (GARS, PSE-RooPRIoor)

was.having.to of bred

'my mother sort of knew that day how much bred was needed' 
c. Ah moi je crois pas, parce que faut pas oublier que derrière oh me I believe not since must not to.forget that behind de Gaulle il y a Pompidou (Eschmann, I984: Io2f.) de Gaulle it there has Pompidou,...

'Oh I don't think so, since one must not forget that behind de Gaulle, there is Pompidou,...'

From these findings as well as in light of the counterexamples in (8c) and (9) above, it appears that no strict correlation holds between the (non-)expression of $I L$ and the (non-)embeddedness of the IC in CF.

Interestingly enough, the non-expression of $I L$ in embedded finite constructions does not represent a recent phenomenon. This at least follows from a scrutiny of the 306 instances of constructions with faut 'must' and non-expressed IL established in the I I 3 pieces of literary work from the mid-I 7 th to the end of the I 9 th century (cf. section 3.2). In fact, as the five relevant instances in (I I) illustrate, the nonexpression of $I L$ in embedded finite constructions in CF may be shown to date back to (at least) the mid-I8th century. This is a natural finding, given that the non-expression of $I L$ in ICs in CF represents the continuation of a grammatical trait of older stages of French in which all ICs may have IL non-expressed.

(I I) a. ; mais, c' eft qu' faut faire fes affaires,... (henri, I766, p. 95) but this is that must to.make his things

'; but it's because one must do his business, ...'

b. ... et puis c' est que faut dire aussi que... (actrice, I825, p. I7) and then this is that must to.say also that

'.. and then it's because one must also say that ...'

c. ..., parce que faut que vous sachiez qu'... (anonyme, I826, p. 3I)

since must that you know that

'..., since you must know that...'

d. V'là l' port vers lequel faut qu' tu cingles;

there the harbor towards which must that you sail

(augusta, I833, p. I7)

'There is the harbor into which you must put;'

e. ..., c' est qu' voyez-vous à dix heures, faut r'prendre le this is that see you at ten o'clock must to.pick.up the

collier d' misère! (augusta, I833, p. 20)

necklace of misery

'..., it's because, you see, at ten o'clock, one must pick up one's necklace of misery!'

Note that these examples further substantiate the observation that no strict correlation holds between the (non-)expression of IL and the (non-)embeddedness of the IC in CF. Yet, according to the search of the three modern synchronic data 
corpora of spoken French for instances of root finite constructions with falloir 'to have to' (cf. Table 3), the basic claim of a root-embedded-asymmetry regarding the (non-)expression of IL seems to be corroborated.

Table 3. Root finite constructions with falloir 'to have to'

\begin{tabular}{lllcr}
\hline \hline corpus & & $I L$ expressed & $I L$ non-expressed & $\Sigma$ \\
\hline GARS & $\#$ & 753 & 207 & 960 \\
& $\%$ & 78.4 & $2 \mathrm{I} .6$ & IOO \\
Ludwig (I988) & $\#$ & 28 & 7 & 35 \\
& $\%$ & 80 & 20 & IOO \\
Eschmann (I984) & $\#$ & 38 & 34 & 72 \\
& $\%$ & 52.8 & 47.2 & IOO \\
\hline \hline
\end{tabular}

A comparison of the results of this search with those of the previous search (cf. Table 2 above), illustrated in Figure I, clearly shows that IL is considerably more frequently non-expressed in root than in embedded finite constructions.

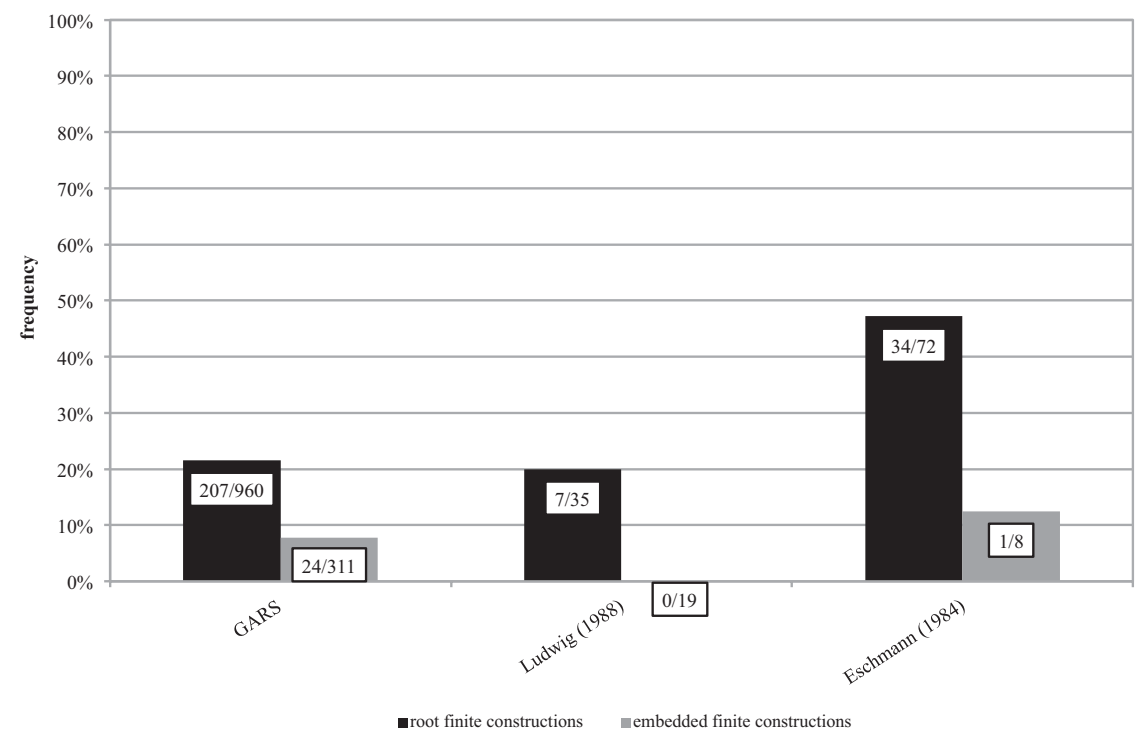

Figure I. Finite constructions with falloir 'to have to' and non-expressed $\mathrm{IL}^{\mathrm{II}}$

Intriguingly, the state of affairs established for CF is highly reminiscent of the one in Medieval French in which the (non-)expression of IL likewise stands out due to a distinct root-embedded-asymmetry, as shown in Figure 2 for prose texts (Zimmermann, 2012).

11 In addition to the respective frequencies illustrated in the form of bars, Figures $\mathrm{I}$ and 2 give the absolute numbers of non-expressed expletive subject pronouns in boxes, followed by the absolute numbers of ICs. 


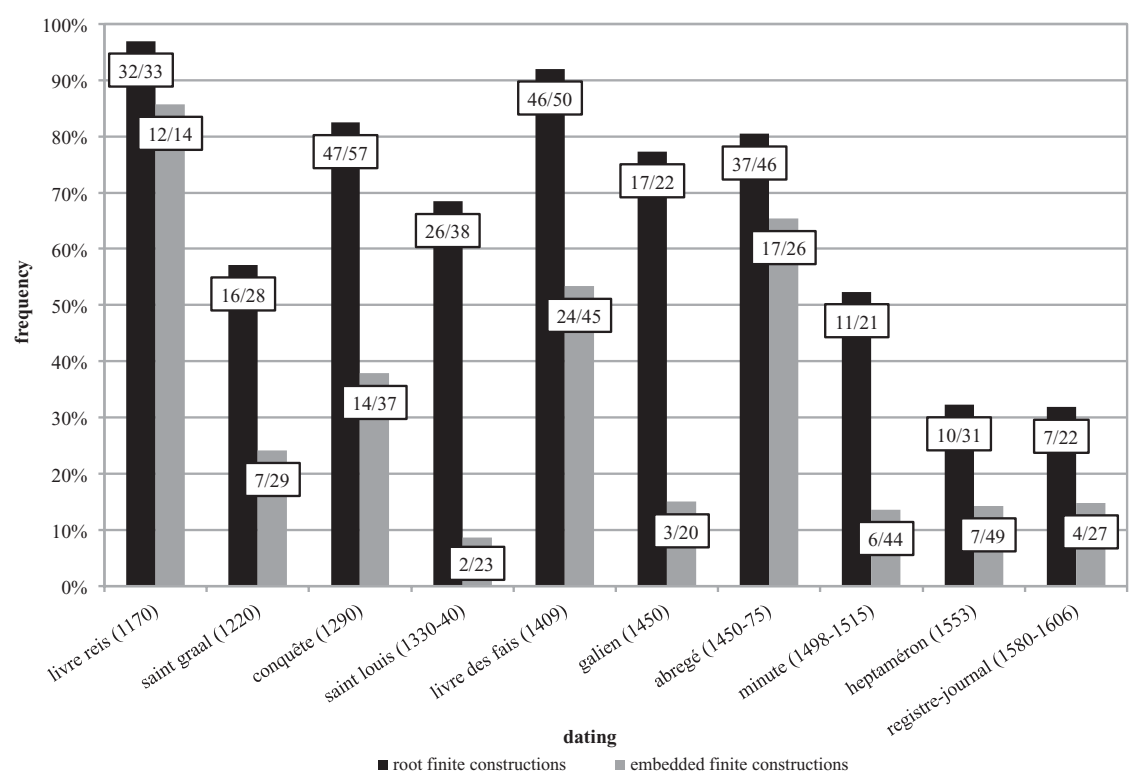

Figure 2. Finite ICs with non-expressed expletive subject pronouns ${ }^{\mathrm{I2}}$

This similarity is all the more remarkable in view of the crucial finding that as shown in section 3.2, the non-expression of IL in ICs in CF represents the continuation of a grammatical trait of Medieval French.

To summarise, at least with regard to ICs with falloir 'to have to', the nonexpression of $I L$ in CF seems to be syntactically restricted, in that there is a distinct root-embedded-asymmetry. This crucial finding clearly indicates that this nonexpression of $I L$ represents evidence against, rather than for the approach to the status of clitic subject pronouns in CF in terms of inflectional affixes. What remains, however, fairly unclear - regardless of the analysis one eventually adopts with regard to clitic subject pronouns in $\mathrm{CF}$ - is what exactly lies behind the non-expression of $I L$. In the next section, we shall briefly turn to this yet again intricate issue and provide a tentative account of it.

\section{ACCOUNTING FOR THE NON-EXPRESSION OF $I L$ IN ICS}

The intriguing nature of the non-expression of $I L$ in ICs in CF stems from the fact that with the additional exception of a highly restricted conventionalised set of (personal) constructions (cf. section I), finite constructions without any subject

12 Figure 2 is based on an interpolation of the results of the processing of an extensive diachronic data corpus in Zimmermann (2012). 
are otherwise illicit in CF. The crucial question in this regard is, why may $I L$ be non-expressed in constructions with the impersonal verbs in (2) (cf. section 2)? According to the discussion in section 3, functional, morphological and rhetorical approaches must be ruled out. Instead, a syntactic approach appears to be in order, especially in view of the major findings that (i) the non-expression of IL in CF evidently represents the continuation of a grammatical trait of older stages of French and that (ii), as in these stages, it is (to some extent) dependent on the (non-)embeddedness of the IC.

On the basis of these findings, we essentially argue that ICs with non-expressed $I L$ in CF constitute a restricted set of residual Medieval French constructions contemporary speakers of CF may additionally resort to. It thus seems to be a natural step to assume that in $\mathrm{CF}$, the non-expression of $I L$ follows from the same reasons as the non-expression of subject pronouns in older stages of French. Regarding these stages, it is generally claimed in generative approaches that subject pronouns may be non-expressed in configurations of the type $\left[\mathrm{V}_{[+ \text {finite] }}\right.$ pro $]$ in which the finite verb, as the governing head, licenses the subject position and identifies, by means of its agreement features, the content of the subject. What is crucial in this regard is the central - and empirically well motivated - assumption that in cases of non-expressed subject pronouns, the finite verb must move to some head position in the left periphery to meet the required licensing and identification requirements. Note that if it is indeed the case that (i) in CF, the non-expression of $I L$ follows from the very same reasons as the non-expression of subject pronouns in Medieval French and that (ii) this non-expression is a direct result of verb movement, then the non-expression of IL may be considered theoretical evidence against the approach to the status of clitic subject pronouns in CF in terms of inflectional affixes.

Even though the analysis just outlined generally underlies generative approaches to the non-expression of subject pronouns in older stages of French, almost all of these refrain from expounding on the exact reasons lying behind the left-peripheral movement of the finite verb. Those who have provided for an account do so by drawing on information structure. Specifically, the further movement of the finite verb has been motivated either in terms of a Topic Criterion (Vance, 1997) or a Focus Criterion (Zimmermann, 20I2; cf. also Kaiser and Zimmermann, 20II). Under these accounts, the movement of the finite verb to a left-peripheral head position thus follows from the fulfillment of either one of these criteria, namely whenever some phrasal non-subject constituent or the finite verb itself is topicalised and focused, respectively. Given that the vast majority of ICs with non-expressed $I L$ in $C F$ constitute constructions in which the finite verb is in first position, we tentatively assume that in these constructions, the movement of the finite verb follows from either its topicalisation or focalisation. Under this assumption, then, ICs with non-expressed $I L$ constitute a restricted set of residual medieval French constructions contemporary speakers of CF may additionally resort to, whenever the impersonal verb either represents known information or brings into special prominence new information. 
To illustrate, consider the sentence in (9b), repeated in (12), which features both a root and an embedded finite construction with falloir 'to have to'.

(I2) Quand faut $y$ aller faut $y$ aller. when must there to.go must there to.go 'A man's gotta do what a man's gotta do!'

With regard to the embedded construction, the impersonal verb faut 'must', together with its complement, may well be considered topicalised, since this construction represents a reiteration of the root construction. As for faut 'must' in the root construction, special emphasis may be argued to be on the notion of the urgent necessity that something is to be done, so that in this construction, the finite verb may be considered specially focused.

Note, finally, that under the present account of ICs with non-expressed IL in $\mathrm{CF}$, the distinctly lower frequency in this non-expression of $I L$ in embedded clauses may be argued to directly follow from functional specificities of clause types, in that topicalisation and focalisation are more marked in embedded than in root clauses (Price, I96I; Roberts, I993). The present account, then, allows to capture both the non-expression of IL in ICs in CF and its overall distribution.

Address for correspondence:

Universität Konstanz

Fachbereich Sprachwissenschaft

Fach 189

D-78457 Konstanz

Germany

e-mail: Michael.Zimmermann@uni-konstanz.de Georg.Kaiser@uni-konstanz.de

\section{REFERENCES}

Auger, J. (I993). More evidence for verbal agreement-marking in colloquial French. In: W.J. Ashby, M. Mithun, G. Perissinotto and E. Raposo (eds), Linguistic Perspectives on the Romance Languages. Selected Papers from the $21^{\text {st }}$ Linguistic Symposium on Romance Languages. (Amsterdam Studies in the Theory and History of Linguistic Science, IV; Current Issues in Linguistic Theory, I03). Amsterdam: Benjamins, pp. I77-I98.

Barme, S. (2012). Gesprochenes Französisch. (Romanistische Arbeitshefte, 58). Berlin: De Gruyter.

Berrendonner, A. (I993). Sujets zéro. In: S. Karolak and T. Muryn (eds), Complétude et incomplétude dans les langues romanes et slaves. Actes du VIe colloque international de linguistique romane et slave. Cracow: WSP, pp. I7-43.

Brugmann, K. (I9I7). Der Ursprung des Scheinsubjekts 'es' in den germanischen und den romanischen Sprachen. (Berichte über die Verhandlungen der Königl. Sächsischen Gesellschaft der Wissenschaften zu Leipzig: Philologisch-historische Klasse, 69). Leipzig: Teubner. 
Brunot, F. (I89i). La doctrine de Malherbe d'après son commentaire sur Desportes avec 5 planches hors texte. Paris: Masson.

Buridant, C. (2007). Grammaire nouvelle de l'ancien français. Reprint. Paris: Sedes.

Chiflet, L. (I659). Essay d'une parfaite grammaire de la langue françoise. Anvers: van Meurs.

Chigarevskaia, N. (I968). Sur les constructions impersonnelles en français parlé d'aujourd'hui. Annales de la Faculté des Lettres et Sciences Humaines d'Aix, 44: 36I367.

Culbertson, J. (2010). Convergent evidence for categorial change in French: From subject clitic to agreement marker. Language, 86: 85-I32.

Damourette, J. and Pichon, E. (I934). L'ostension. Les unipersonnels. In: J. Damourette and E. Pichon (eds), Des mots à la pensée. Essai de grammaire de la langue française, vol. 4. Paris: D'Artrey, pp. 463-542.

Diehl, R. (I895). Französische Schulgrammatik und moderner Sprachgebrauch. Städtische Oberrealschule zu Wiesbaden. Jahresbericht über das Schuljahr 1894/95. (Programm-Nummer, 43 I). Wiesbaden: Schwab, pp. 3-I9.

Dupuis, F. (1988). Pro-drop dans les subordonnées en ancien français. Revue québecoise de linguistique théorique et appliquée, 7: 4I-62.

Eschmann, J. (I984). Texte aus dem 'français parlé'. (Tübinger Beiträge zur Linguistik, 257). Tübingen: Narr.

Fonseca-Greber, B.B. (2004). Zero marking in French impersonal verbs: A counter trend to clitic morphologization? Proceedings of the Annual Meeting of the Berkeley Linguistics Society, 30: 8I-92.

Gaatone, D. (1976). Il doit y avoir - *il faut y avoir. A propos de la "montée du sujet". Revue Romane, I I: 245-266.

Gabriel, C. and Müller, N. (2013). Grundlagen der generativen Syntax. Französisch, Italienisch, Spanisch, 2nd revised edn. (Romanistische Arbeitshefte, 5I). Tübingen: Niemeyer.

Gadet, F. (I997). Le français populaire, 2nd revised edn. (Que sais-je ?, I I72). Paris: Presses Universitaires de France.

Grevisse, M. and Goosse, A. (20 I I). Le bon usage. Grammaire française, i 5 th edn. Paris: De Boeck and Duculot.

Haas, J. (I909). Neufranzösische Syntax. (Sammlung kurzer Lehrbücher der romanischen Sprachen und Literaturen, 4). Halle: Niemeyer.

Heriau, M. (1980). Le verbe impersonnel en français moderne, vol. I. Doctoral dissertation, Université de Haute Bretagne. Paris: Champion.

Kaiser, G. A. (2008). Zur Grammatikalisierung der französischen Personalpronomina. In: E. Stark, R. Schmidt-Riese and E. Stoll (eds), Romanische Syntax im Wandel. Tübingen: Narr, pp. 305-325.

Kaiser, G. A. and Zimmermann, M. (20 I I). On the decrease in subject-verb inversion in French declaratives. In: E. Rinke and T. Kupisch (eds), The Development of Grammar. Language Acquisition and Diachronic Change. In Honour of Jürgen $M$. Meisel. (Hamburg Studies on Multilingualism, I I). Amsterdam: Benjamins, pp. 355$38 \mathrm{I}$.

Koch, P. and Oesterreicher, W. (20I I). Gesprochene Sprache in der Romania: Französisch, Italienisch, Spanisch. (Romanistische Arbeitshefte, 3 I). Berlin: De Gruyter.

Leeman, D. (2006). L'absence du sujet en français contemporain. Premiers éléments d'une recherche. L'information grammaticale, I Iо: 23-30.

Le Goffic, P. (I993). Grammaire de la phrase française. Paris: Hachette. 
Ludwig, R. (1988). Korpus: Texte des gesprochenen Französisch. Materialien 1. (ScriptOralia, 8). Tübingen: Narr.

Maillard, M. (I985). L'impersonnel français de il à ça. In: J. Chocheyras (ed.), Autour de l'impersonnel. Grenoble: Ellug, pp. 63-I I 8.

Maillard, M. and Almeida, E. (2000). Un modèle nodal pour une description cohérente de l'impersonnel en français et en portugais. Cahiers de l'ILSL, I2: I73206.

Meisenburg, T. (2000). Vom Wort zum Flexiv? Zu den französischen Pronominalklitika. Zeitschrift für französische Sprache und Literatur, I I0: 223-237.

Oppermann-Marsaux, E. (2006). Quelques remarques sur l'emploi et le non-emploi du «il impersonnel» entre le XIVe et le XVIIe siècle. L'information grammaticale, i Io: 9-I4.

Picoche, J. and Marchello-Nizia, C. (1998). Histoire de la langue française, 5 th, revised edn. Paris: Nathan.

Price, G. (I96I). Aspects de l'ordre des mots dans les «Chroniques» de Froissart. Zeitschrift für romanische Philologie, 77: I 5-48.

Roberts, I.G. (I993). Verbs and diachronic syntax. A comparative history of English and French. (Studies in Natural Language and Linguistic Theory, 28). Dordrecht: Kluwer.

Rohlfs, G. (1928). Volkssprachliche Einflüsse im modernen Französisch. Braunschweig: Westermann.

Rowlett, P. (1998). Sentential Negation in French. New York: Oxford University Press.

Sandfeld, K. (I965). Syntaxe du français contemporain, vol. I. Paris: Champion.

Seefranz-Montag, A. von (1983). Syntaktische Funktionen und Wortstellungsveränderung. Die Entwicklung, ,subjektloser" Konstruktionen in einigen Sprachen. (Studien zur theoretischen Linguistik, 3). München: Fink.

Seefranz-Montag, A. von (I984). 'Subjectless' constructions and syntactic change. In: J. Fisiak (ed.), Historical Syntax. (Trends in Linguistics. Studies and Monographs, 23). Berlin: Mouton de Gruyter, pp. $52 \mathrm{I}-533$.

Siede, J. (I 885). Syntaktische Eigentümlichkeiten der Umgangssprache weniger gebildeter Pariser beobachtet in den Scènes populaires von Henri Monnier. (Doctoral dissertation, FriedrichWilhelms-Universität Berlin). Berlin: Mayer and Müller.

Söll, L. (1985). Gesprochenes und geschriebenes Französisch, $3 \mathrm{rd}$, revised edn by FJ. Hausmann. (Grundlagen der Romanistik, 6). Berlin: Schmidt.

Steinmeyer, G. (1979). Historische Aspekte des français avancé. Geneva: Droz.

Vance, B. S. (1997). Syntactic Change in Medieval French. Verb-Second and Null Subjects. (Studies in Natural Language and Linguistic Theory, 4I). Dordrecht: Kluwer.

Zimmermann, M. (2012). The Evolution of Expletive Subject Pronouns in French. Doctoral dissertation. Universität Konstanz.

Zribi-Hertz, A. (I994). The syntax of nominative clitics in standard and advanced French. In: G. Cinque, J. Koster, J-Y. Pollock, L. Rizi \& R. Zanuttini (eds), Paths Towards Universal Grammar. Studies in Honor of Richard S. Kayne. (Georgetown Studies in Romance Linguistics). Georgetown: Georgetown University Press, pp. 453-472.

Zribi-Hertz, A. (20 I I). Pour un modèle diglossique de description du français: quelques implications théoriques, didactiques et méthodiques. French Language Studies, 2 I: 23 I256.

Zwicky, A. M. and Pullum, G. K. (1983). Cliticization vs. inflection: English n't. Language, 59, 3: 502-5 I3. 


\section{TEXT EDITIONS CONSULTED}

accordée: $\quad$ Brazier, Carmouche and Jouslin de La Salle (I 824). L'Accordée du village, comedie-vaudeville en un acte. Paris: Pollet.

actrice: $\quad$ Eugène (I 825 ). L'Actrice chez elle, ou C'est ma femme, comédie-vaudeville en un acte. Paris: Barba.

ange: $\quad$ Lajariette and Delacour (I 848). L'ange de ma tante. Comédie-vaudeville en un acte. Paris: Beck.

anonyme: Dupeuty, De Villeneuve and Jouslin de La Salle (I 826). L'Anonyme, comédie-vaudeville en deux actes. Paris: Bezou.

augusta: $\quad$ Simonnin (I 833). Augusta, ou Comme on Corrige une Jeune Personne, comédie-vaudeville en deux actes. (Répertoire dramatique de l'enfance et de la jeunesse, 3). Paris: Bréauté.

barbier: Beaumarchais (I775). Le barbier de Séville, ou La precaution inutile, comédie en quatre actes. Paris: Ruault.

boutades: [Scarron] (I 647). Les bovtades dv capitan Matamore et ses comédies. Paris: Sommaville.

brigands: $\quad$ Meilhac, H. and Halévy, L. (187I). Les Brigands. Opera Bouffe en Trois Actes. London: Boosey.

conqueste: J. de Vileharduyn. La conqueste de Costentinoble d'après le manuscrit $n^{\circ} 2137$ de la B.N. (Travaux du C.R.A.L. I). Nancy: Centre de Recherches et d'Applications Linguistiques, Université de Nancy II I978.

henri: $\quad$ Collé (I766). La partie de chasse de Henri IV, Comédie En trois Actes E en Profe. Paris: Duchesne and Gueffier.

heritier: [Marivaux] (I729). L'heritier de village. Comedie. En un acte. Paris: Briasson.

lotterie: Dancourt (I697). La lotterie, comedie. Paris: Guillain.

louis: Joinville. Vie de saint Louis. Texte établi, traduit, présenté et annoté avec variantes par J. Monfrin. Paris: Dunod I995.

nanine: $\quad$ Voltaire (I750). CEuvres de $M^{r}$ de Voltaire, new, revised, corrected, and considerably augmented edn, vol. 9. Dresden: Walther.

pierre: $\quad$ Maupassant, Guy de (I 888). Pierre et Jean. Paris: Ollendorf.

roland: La Chanson de Roland. Edizione critica a cura di C. Segre. (Documenti di Filologia I6). Milano: Ricciardi I97I.

sganarelle: Molière (i660). Sganarelle ov Le cocv imaginaire. Comedie. Auec les Arguments de chaque Scene. Paris: Ribov.

sabotiers: Pigault Lebrun (I796). Les sabotiers, comèdie en un acte et en prose, mêlée de chant. Paris: Huet. 